\title{
Porous Stainless Steel for Biomedical Applications
}

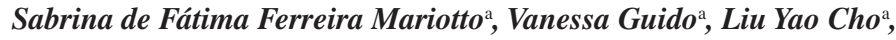 \\ Cristina Pacheco Soares ${ }^{\mathrm{a}}$, Kátia Regina Cardoso ${ }^{\mathrm{a}, \mathrm{b}} *$
}

\author{
anstituto de Pesquisa e Desenvolvimento, Universidade do Vale do Paraíba - UNIVAP, \\ Av. Shishima Hifumi, 2911, Urbanova, CEP 12244-000, São José dos Campos, SP, Brazil \\ ${ }^{\mathrm{b}}$ Instituto de Ciência e Tecnologia, Universidade Federal de São Paulo - UNIFESP, \\ Rua Talim, 330, Vila Nair, CEP 12231-280, São José dos Campos, SP, Brasil
}

Received: September 3, 2010; Revised: March 11, 2011

\begin{abstract}
Porous $316 \mathrm{~L}$ austenitic stainless steel was synthesized by powder metallurgy with relative density of 0.50 and 0.30 using 15 and $30 \mathrm{wt}$. (\%) respectively of ammonium carbonate and ammonium bicarbonate as foaming agents. The powders were mixed in a planetary ball mill at $60 \mathrm{rpm}$ for 10 minutes. The samples were uniaxially pressed at $287 \mathrm{MPa}$ and subsequently vacuum heat treated in two stages, the first one at $200{ }^{\circ} \mathrm{C}$ for 5 hours to decompose the carbonate and the second one at $1150{ }^{\circ} \mathrm{C}$ for 2 hours to sinter the steel. The sintered samples had a close porous structure and a multimodal pore size distribution that varied with the foaming agent and its concentration. The samples obtained by addition of $30 \mathrm{wt}$. (\%) of foaming agents had a more homogeneous porous structure than that obtained with $15 \mathrm{wt}$. (\%). The MTT cytotoxicity test (3-[4,5-dimethylthiazol]-2,5-diphenyltetrazolium bromide) was used to evaluate the mitochondrial activity of L929 cells with samples for periods of 24, 48, and 72 hours. The cytotoxicity test showed that the steel foams were not toxic to fibroblast culture. The sample with the best cellular growth, therefore the most suitable for biomedical applications among those studied in this work, was produced with $30 \mathrm{wt}$. (\%) ammonium carbonate. In this sample, cell development was observed after 48 hours of incubation, and there was adhesion and spreading on the material after 72 hours. Electrochemical experiments using a chloride-containing medium were performed on steel foams and compared to massive steel. The massive steel had a better corrosion performance than the foams as the porosity contributes to increase the surface area exposed to the corrosive medium.
\end{abstract}

Keywords: stainless steel, cellular solids, powder metallurgy, cytotoxicity

\section{Introduction}

Austenitic stainless steels are frequently used in biomedical applications, such as orthopedic implants, due to properties like high corrosion and fatigue resistance as well as high fracture toughness. In addition to biocompatibility, these properties are important in the selection and adaptation of a material for biomedical applications. However, the major problem concerning orthopedic metallic implants is the mismatch of Young's modulus between bone and bulk metallic material. Due to this mechanical mismatch, bone is insufficiently loaded and becomes stress shielded, which eventually leads to bone reabsorption. If the bone loss is excessive, it can compromise the long-term performance of the prosthesis ${ }^{1-3}$.

Metal foams with extremely low density and good combination of properties have excellent potential for implant application because of the reduced stiffness mismatches ${ }^{4}$. Additionally, bone ingrowth is possible, which could greatly improve the bone-implant interface and may allow for efficient soft tissue attachment supplementing the stability of the implant by biological fixation ${ }^{5,6}$. The greatest application fields are in the osseous reconstructive surgery, such as treatment of small bone defects, cranio-maxillofacial reconstruction, tooth root replacements and vertebral body replacement ${ }^{6}$.

Open-cell and closed-cell are the major classification of porous metals, or metal foams. In closed-cell foams, each cell is completely enclosed by a thin wall or membrane of metal, whilst in open-cell foams the individual cells are interconnected, allowing tissue to infiltrate the foam and anchor it into position. Although open-cell metals are preferred for use in implants because they facilitate bone ingrowth, metals with a closed-cell structure may be used in orthopedic load bearing implants ${ }^{1}$.

The selection of materials for medical applications is also based on considerations of in vivo performance. The orthopedic prostheses are commonly used for extended time and are subject to a highly aggressive medium that constitutes the human body, fluids rich in sodium chloride. Therefore, when metals and alloys are considered, the susceptibility of the material to corrosion and its local and systemic effects should be considered. The corrosion product can cause changes in the histology of local tissue either by toxic effects as by local hypersensitive. This biological response may cause loss of part of implant and surgical revisions ${ }^{1}$. Corrosion resistance of the currently used $316 \mathrm{~L}$ stainless steel relies on their passivation by a thin surface layer of oxide. However, studies ${ }^{1,7}$ have demonstrated that porous $316 \mathrm{~L}$ exhibited poor corrosion resistance due to potentially higher corrosion rates that can occur in vivo with the irregular and porous surface geometry. Seah et al. ${ }^{8}$ showed that corrosion resistance decreased with decreasing porosity, which was attributed to the small, isolated pore morphology that traps ionic species and restricts the access of oxygen, which in turn limits the available oxygen for the formation of the corrosion resistant passive layers. In highly porous compacts with an open, interconnected pore morphology, the free flow of species resulted in a material with increased corrosion resistance.

Different processes have been used in the fabrication of porous metals ${ }^{1,9}$. Casting or vapor deposition techniques tend to allow greater control over pore size, distribution, and interconnectivity, 
which produce open-cell geometries. Other processes involving decomposition of foaming agents in either molten or powder metal matrices ${ }^{10,11}$ give lower porosity and less predictable pore distribution and interconnectivity. In the 'Fraunhofer' process ${ }^{12}$, which has been successfully used to make closed-cell aluminum foams, the metal powder is blended with a granular foaming agent and compacted by conventional means, yielding a fully dense semi finished product. The compact is expanded to foam by heating it to the melting point, $T_{\mathrm{m}}$, whereupon gas is evolved from the decomposition of the foaming agent. In this method, the foaming agent must undergo thermal decomposition near $T_{\mathrm{m}}$ and generate gas pressure in the metal matrix sufficient to overcome atmospheric pressure and cause foaming. Foam expansion results in closed-cell foam with a relative density of $0.2-0.8$, depending on the particular process parameters employed $^{12,13}$. The syntheses of steel foams by this route are difficult because of the high melting point and the low melt viscosity of steel. A similar process was used to produce a porous structure in $\mathrm{TiZr}^{2}$ and Ti-Sn-Nb alloys ${ }^{14}$. Particles of ammonium hydrogen carbonate were used as the space-holding material. This carbonate decomposes at low temperature, then the metal foams were obtained in the solid state during a two-stage heat treatment to burnout the space-holding particles $\left(\sim 200^{\circ} \mathrm{C}\right)$ and to sinter the steel $\left(1200-1300{ }^{\circ} \mathrm{C}\right)$.

The aim of this work was to investigate the feasibility of synthesizing porous $316 \mathrm{~L}$ stainless steel samples by powder metallurgy route using ammonium carbonate and ammonium bicarbonate as foaming agents and a two-stage heat treatment to sinter the steel. The effect of foaming agent and its concentration on the development of the pore structure and corrosion properties were evaluated. The MTT (3-[4,5-dimethylthiazol]-2,5-diphenyltetrazolium bromide) colorimetric assay was used to measure cytotoxicity and cell proliferation and to assess the suitability of the material for biomedical applications.

\section{Materials and Methods}

The composition of commercial 316L stainless steel powder specified by the AMS 5507D is presented in Table 1, while Table 2 presents the granulometric analysis of steel powder certified by the supplier. The steel powder was mixed with the foaming agents: ammonium carbonate and ammonium bicarbonate, in a planetary ball mill at $60 \mathrm{rpm}$ for 10 minutes with a ball to powder weight ratio of 28:1. Mixtures were produced with 15 and $30 \mathrm{wt}$. (\%) ammonium carbonate and bicarbonate with the aim of producing porous samples with relative density of 0.5 and 0.3 , respectively. The samples were uniaxially pressed at $287 \mathrm{MPa}$ and then vacuum heat treated $\left(10^{-2} \mathrm{bar}\right)$ in two stages, the first one at $200{ }^{\circ} \mathrm{C}$ for 5 hours to decompose the carbonate and the second one at $1150{ }^{\circ} \mathrm{C}$ for 2 hours to sinter the steel. Twenty samples were produced for each condition with $10 \mathrm{~mm}$ in diameter for the citotoxicity assays. The samples for electrochemical experiments were $20 \mathrm{~cm}$ in diameter. Samples of pure $316 \mathrm{~L}$ stainless steel (no porous material) were also produced and sintered at $1150{ }^{\circ} \mathrm{C}$ for 2 hours in high vacuum $\left(10^{-6}\right.$ bar $)$ in order to minimize the oxidation and compare the effect of the pores in the cytotoxicity test.

The apparent density and relative density was determined for all samples (twenty for each condition) in the green and sintered states. The apparent density was measured using the mass and dimensions of samples $\left(\rho_{\mathrm{g}}\right)$ and the relative density $\left(\rho_{\mathrm{r}}\right)$ was calculated as the ratio of the apparent density and theoretical density calculated for each mixture. Helium pycnometry was used to determine the true density $\left(\rho_{t}\right)$ of the samples. The open porosity $\left(P_{o}\right)$ was estimated from the relation between the true density and the geometrical density, according to the expression: $P_{o}=\left(1-\left(\rho_{g} / \rho_{t}\right)\right)$. The pore size distribution was analyzed by mercury porosimetry over a pressure range of 0 to $50 \mathrm{psi}$. The samples were submitted to a heat treatment at $120^{\circ} \mathrm{C}$ for 2 hours to clean and eliminate moisture before the pore size distribution analyses. Morphological characterization was carried out by optical and scanning electronic microscopy (SEM).

The cytotoxicity assay was evaluated according to ISO 10993-5 "Biological evaluation of medical devices - Test for cytotoxicity: in vitro methods" (or EN 30993-5), using direct contact. The proliferate activity of cultured cells was determined with the MTT (3-[4,5-dimethylthiazol]-2,5-diphenyltetrazolium bromide) colorimetric assay, as described by Mosmann ${ }^{15}$. Latex fragments were used as the positive control and fragments of proven non-toxic paper filter were used as the negative control. The dimensions of these fragments were the same of the samples. All the samples were sterilized for 24 hours under UV irradiation and placed in individual wells of 24-well culture plates. L929 cells were inoculated in each well at a concentration of $5 \times 10^{5}$ cells. $\mathrm{mL}^{-1}$, supplemented with $10 \%$ fetal bovine serum (Gibco, BRL). The incubation was performed under a $\mathrm{CO}_{2}(5 \%)$ atmosphere at $37{ }^{\circ} \mathrm{C}$ for different times. The viability of cells was determined after 24,48 and 72 hours. After the incubation time, the samples and the positive and negative control fragments were removed from the respective wells. Only the cells that adhered to the well walls were incubated with a tetrazolium salt solution (MTT), (3-[4,5-dimethylthiazol]-2,5-diphenyltetrazolium bromide) (Sigma, St. Louis, MO, USA) for 4 hours at $37^{\circ} \mathrm{C}$. The MTT was reduced to an insoluble formazan precipitate by mitochondrial succinic dehydrogenase of the viable cells. After removal of the medium, ethanol-dimethyl sulfoxide (DMSO) (Sigma) solution (1:1) was added to each well. After complete solubilization of the dark blue crystal of MTT formazan, the absorbance of the content of wells was measured at $570 \mathrm{~nm}$ with a 24-well microplate reader on a spectrophotometer Spectra Count (Packard). The blank reference was taken from wells without cells, which were also incubated with the MTT solution. The cell viability was calculated by the normalization of optical densities (OD) using the following expression:

$$
\begin{gathered}
\text { Cell } \\
\text { viability }(\%)
\end{gathered}=\frac{\begin{array}{c}
\text { absorbance of } \\
\text { cells on samples }
\end{array}}{-\begin{array}{c}
\text { absorbance of } \\
\text { blank reference }
\end{array}}
$$

The cellular adhesion capacity of the L929 cells on the samples was tested at incubation periods of 48 and 72 hours. After the culture, the cells attached on the samples were fixed in $3 \%$ glutaraldehyde in $0.1 \mathrm{M}$ sodium cacodylate buffer for 1 hour and dehydrated in a graded ethanol solution series $(30,50,70,95,100 \%)$ for 10 minutes each. The drying stage used a solution of ethanol (50\%) with

Table 1. Chemical Composition in weight percent of stainless steel 316L (AMS 5507D).

\begin{tabular}{cccccccccc}
\hline Composition & $\mathrm{Cr}$ & $\mathrm{Ni}$ & $\mathrm{Mn}$ & $\mathrm{Si}$ & $\mathrm{S}$ & $\mathrm{C}$ & $\mathrm{P}$ & $\mathrm{Mo}$ & $\mathrm{Fe}$ \\
\hline wt. $(\%)$ & 18.0 & 14.0 & 0.5 & 1.0 & 0.03 & 0.03 & 0.045 & 3.0 & balance \\
\hline
\end{tabular}

Table 2. Particle size distribution (weight \%) of 316L stainless steel (certified by supplier).

\begin{tabular}{ccc}
\hline $\begin{array}{c}\text { Mesh size } \\
(\text { ASTM })\end{array}$ & $\begin{array}{c}\text { Minimum value } \\
(\text { wt. }(\%))\end{array}$ & $\begin{array}{c}\text { Maximum value } \\
(\text { wt. }(\%))\end{array}$ \\
\hline+100 & - & 3 \\
+150 & 8 & 12 \\
+325 & 32 & 36 \\
-325 & 35 & 45 \\
\hline
\end{tabular}


hexamethyldisilazane (HMDS) and HMDS (100\%) for 10 minutes respectively. SEM characterization was done on dried samples.

Electrochemical study was carried out on massive steel and steel foams produced with 15 wt. (\%) ammonium carbonate and bicarbonate with a Potentiostat/Galvanostat model MQPG-01 Microquimica. The electrochemical experiments were performed at $25^{\circ} \mathrm{C}$ in a one-compartment cell containing three electrodes. The working electrodes were the $316 \mathrm{~L}$ steel foams and the massive one inlaid on Teflon ${ }^{\circledR}$, with a $0.79 \mathrm{~cm}^{2}$ disc shaped exposed area. The reference electrode was a saturated $\mathrm{Ag} / \mathrm{AgCl}, \mathrm{Cl}^{-}$electrode and the auxiliary electrode was a platinum rod.

The electrochemical experiments were investigated by potentiodynamic polarization curves in a 0.1 mol. $\mathrm{L}^{-1} \mathrm{NaCl}$ solution $(\mathrm{pH}=5.9)$, which was not stirred, open to the atmosphere at $25^{\circ} \mathrm{C}$. The experiments were carried out by varying the potential of electrode at $10 \mathrm{mV} / \mathrm{s}$, from -700 up to $+500 \mathrm{mV}$ and -500 up to $+1500 \mathrm{mV}$, reversing the potential down to $-700 \mathrm{mV}$. The electrochemical parameters were obtained from the Tafel plots.

\section{Results and Discussion}

Apparent density $\left(\rho_{\mathrm{g}}\right)$ and relative density $\left(\rho_{\mathrm{r}}\right)$ at green and sintered states, as well as the picnometry density of $316 \mathrm{~L}$ steel foams and the calculated open porosity are show in Table 3. The average densities of green samples are very close to the theoretical values of the mixtures, so almost full density samples were obtained. The samples synthesized with ammonium carbonate presented relative densities slightly higher than that produced with the ammonium bicarbonate. However, no significant differences are observed if the deviations of the average density values are taken into account. After sintering, steel foams with relative densities of 0.3 and 0.5 were successfully obtained using both foaming agents. Helium picnometry densities are lower than that of theoretical density of $316 \mathrm{~L}$ stainless steel $\left(8 \mathrm{~g} \mathrm{~cm}^{-3}\right)$, showing that about 10 to $20 \%$ of the pores in the steel foams are closed. The steel foam produced with 15 wt. (\%) ammonium carbonate presented the higher fraction of closed pores.

Figure 1 and 2 present, respectively, a comparative set of optical and SEM micrographs of steel foams synthesized with 15 and 30 wt. (\%) ammonium carbonate and bicarbonate. The pore distribution obtained is very heterogeneous and composed by irregular and isolated pores. Large and/or coalesced pores on the edge surface of samples can be observed in Figure 1e, while smaller and isolated pores can be seen in the middle of the samples, Figures 1a-d. This fact occurs probably due to more facility of flow of gas on the surface of the samples. Steel foams produced with 30 wt. (\%) foaming agents show larger pores, which are more homogeneous in size and distribution (Figures 1c, 1d, 2c and 2d) than those produced with 15 wt. (\%) foaming agents, where larger pores are surrounded by small ones (Figures 1a, 1b, 2a and 2b).

Figure 3 shows the pore size distribution obtained by mercury porosimetry. The lowest mercury volume intruded was obtained for the massive steel, according with the largest relative density obtained among the sintered samples. Among the steel foams, those produced with 15 wt. (\%) foaming agents had the largest mercury volumes intruded, indicating, apparently, higher volume fraction of pores in samples with higher relative densities. This result could be explained by the minimum pore size that can be analyzed by the $\mathrm{Hg}$ porosimeter used in this work, which is $1000 \mu \mathrm{m}$. As showed by optical and SEM micrographs, steel foams obtained with $30 \mathrm{wt}$. (\%) foaming agents present larger pores than those of the steel foams produced with 15 wt. (\%). The external regions of the samples are formed by the coalescence of pores as show in Figure 1e. These regions and the larger pores in the steel foams produced with $30 \mathrm{wt}$. (\%) foaming agents might have been full filled with $\mathrm{Hg}$ before pressure was applied, which resulted in a lower intruded volume during analysis. Figure 3 shows also that samples produced with $15 \mathrm{wt}$. (\%) of foaming agents have a large fraction of pores with size smaller than $6 \mu \mathrm{m}$, which is consistent with the micrographs of Figure 1 where a large amount of small pores can be seen around larger ones.

The distribution of open pores less than $1000 \mu \mathrm{m}$ illustrated in Figure 3 shows that steel foam obtained with 15 wt. (\%) ammonium carbonate has a trimodal pore size distribution with a close distribution of pores with mean diameter at $5 \mu \mathrm{m}$ and other two wide distribution at 20 and $300 \mu \mathrm{m}$. The foam obtained with $15 \mathrm{wt}$. (\%) ammonium bicarbonate shows a very similar distribution. Steel foam produced with $30 \mathrm{wt}$. (\%) ammonium carbonate also presented a trimodal pores size distribution, one very close with mean diameter at $10 \mu \mathrm{m}$ and other two at 50 and $450 \mu \mathrm{m}$. The sample produced with $30 \mathrm{wt}$. (\%) bicarbonate presented only a broad distribution with a mean diameter of $70 \mu \mathrm{m}$.

Although optimum pore size required for implant fixation remains undefined, the consensus is that in order to optimize mineralized bone ingrowth, pore sizes between 100 and $400 \mu \mathrm{m}$ are necessary ${ }^{1,16-19}$. However, effective bone ingrowths into porous coatings with pore sizes down to $50 \mu \mathrm{m}$ have been related ${ }^{1}$. Conversely, when the pore size is increased beyond $1 \mathrm{~mm}$ there seems to be an increasing tendency for the formation of fibrous tissue. Based on porous sizes distribution the samples produced with $15 \mathrm{wt}$. (\%) foaming agents and $30 \mathrm{wt}$. (\%) ammonium carbonate seem to be appropriate for applications as biomaterials. However, the morphological analysis by

Table 3. Density at green and sintered states, picnometry density and open porosity of steel foams.

\begin{tabular}{|c|c|c|c|c|c|c|}
\hline \multirow[t]{2}{*}{ Sample } & \multicolumn{2}{|c|}{ Green state } & \multicolumn{4}{|c|}{ Sintered state } \\
\hline & $\begin{array}{c}\text { Green density } \\
\rho_{\mathrm{g}}\left(\mathrm{g} \cdot \mathrm{cm}^{-3}\right)\end{array}$ & $\begin{array}{c}\text { Relative density } \\
\rho_{\mathrm{r}}\end{array}$ & $\begin{array}{c}\text { Apparent density } \\
\rho_{\mathrm{g}}\left(\mathrm{g} \cdot \mathrm{cm}^{-3}\right)\end{array}$ & $\begin{array}{c}\text { Relative density } \\
\rho_{\mathrm{r}}\end{array}$ & $\begin{array}{c}\text { Picnometry density } \\
\mathrm{P}_{\mathrm{t}}\left(\mathrm{g} \cdot \mathrm{cm}^{-3}\right)\end{array}$ & $\begin{array}{c}\text { Open porosity } \\
\mathrm{P}_{\mathrm{o}}(\%)\end{array}$ \\
\hline $\begin{array}{l}316 \mathrm{~L}+15 \text { wt. }(\%) \\
\text { A. Carbonate }\end{array}$ & $4.56 \pm 0.71$ & $0.91 \pm 0.14$ & $4.16 \pm 0.68$ & $0.52 \pm 0.08$ & 5.9575 & 30.17 \\
\hline $\begin{array}{l}316 \mathrm{~L}+15 \text { wt. }(\%) \\
\text { A. Bicarbonate }\end{array}$ & $4.25 \pm 1.04$ & $0.85 \pm 0.21$ & $3.77 \pm 0.91$ & $0.47 \pm 0.11$ & 6.3345 & 40.48 \\
\hline $\begin{array}{l}316 \mathrm{~L}+30 \text { wt. }(\%) \\
\text { A. Carbonate }\end{array}$ & $3.38 \pm 0.69$ & $0.93 \pm 0.19$ & $2.63 \pm 0.42$ & $0.33 \pm 0.05$ & 6.5859 & 60.07 \\
\hline $\begin{array}{l}316 \mathrm{~L}+30 \text { wt. }(\%) \\
\text { A. Bicarbonate }\end{array}$ & $3.30 \pm 0.80$ & $0.90 \pm 0.22$ & $2.42 \pm 0.58$ & $0.30 \pm 0.07$ & 6.7663 & 64.23 \\
\hline 316L steel & $6.78 \pm 0.69$ & $0.85 \pm 0.21$ & $6.98 \pm 1.75$ & $0.87 \pm 0.22$ & 6.5907 & - \\
\hline
\end{tabular}




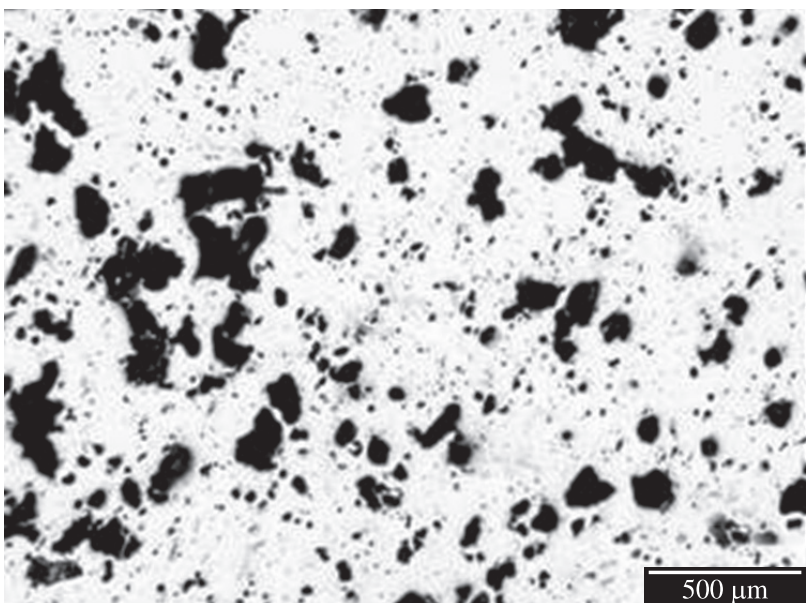

(a)

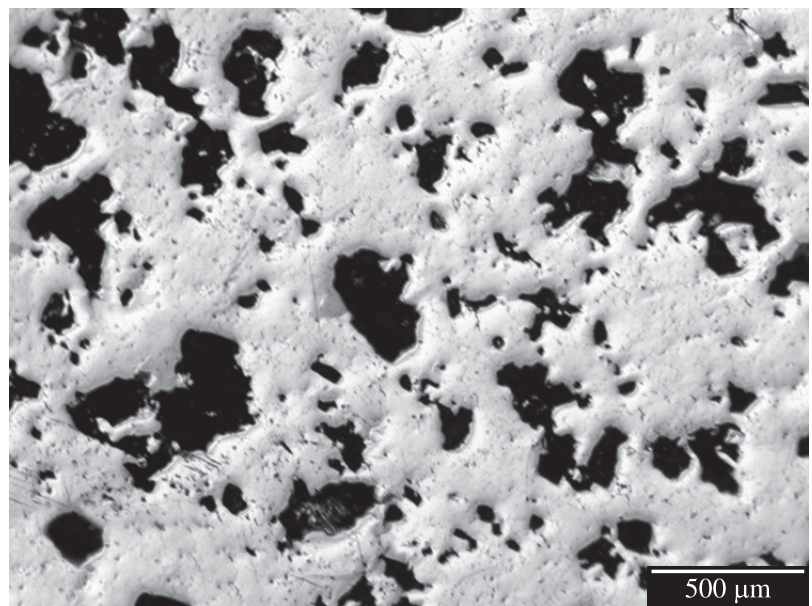

(b)

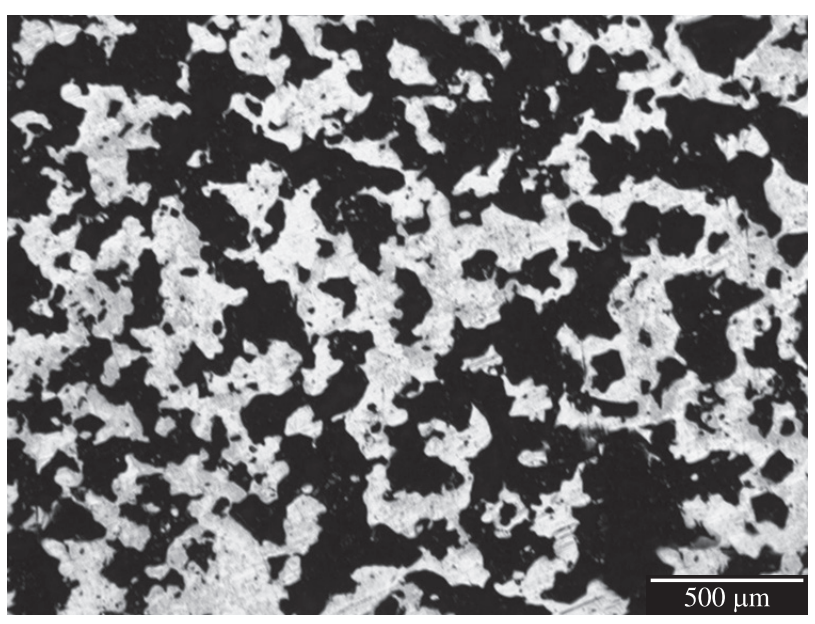

(c)

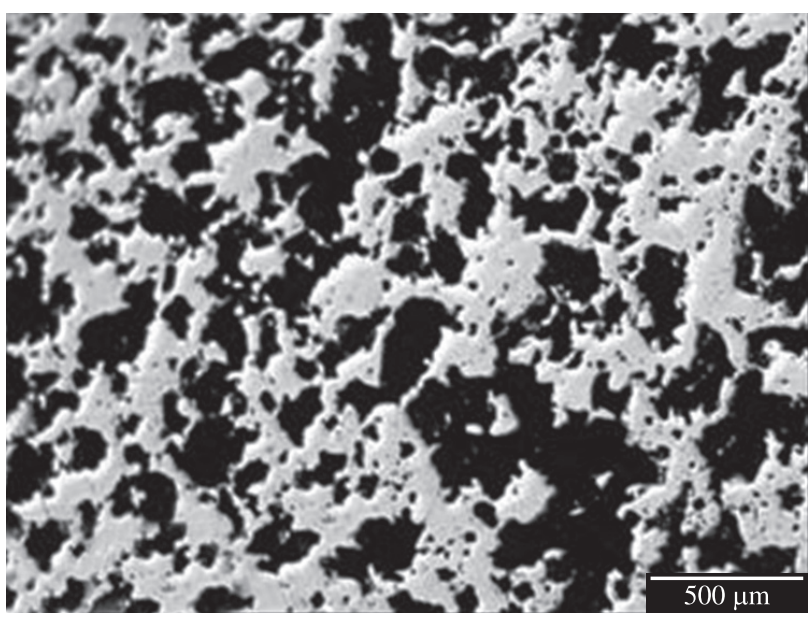

(d)

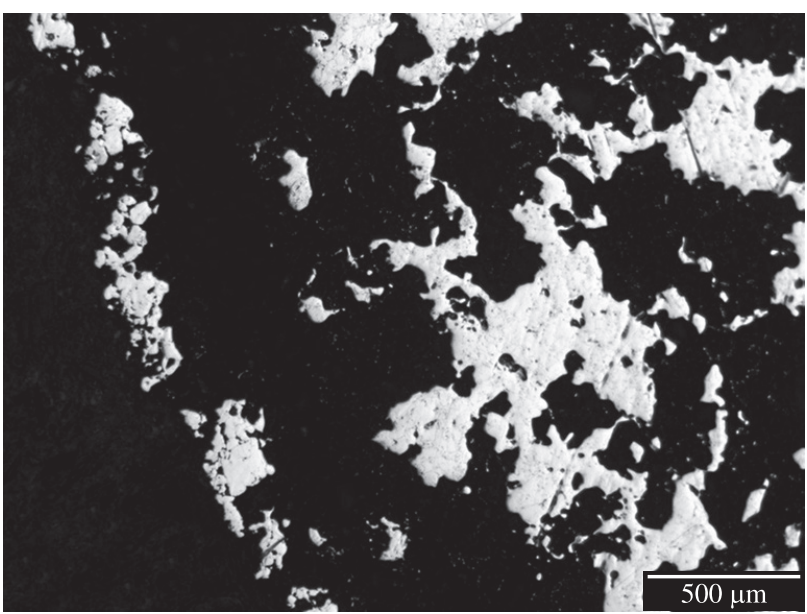

(e)

Figure 1. Optical micrographs of 316L stainless steel foams: a) 15 wt. (\%) ammonium carbonate; b) 15 wt. (\%) ammonium bicarbonate; c) 30 wt. (\%) ammonium carbonate; d) 30 wt. (\%) ammonium bicarbonate; and e) edge of sample with 15 wt. (\%) ammonium carbonate.

microscopy and the open porosity calculations seem to indicate that the $30 \mathrm{wt}$. (\%) ammonium carbonate would be more appropriate for cell ingrowth since it presents a larger amount of regular open pores.

The results of the cytotoxicity tests are presented in Figure 4 in a graph of cell viability against time. The cell viability on pure (no porous) stainless steel was high after 24 hours, showed a significant reduction after 48 hours and was partially recovered after 72 hours. The porous samples showed a significant reduction of cell viability and consequent cellular population after 24 hours when compared with the control groups. However, after 48 hours, the cell viability was 


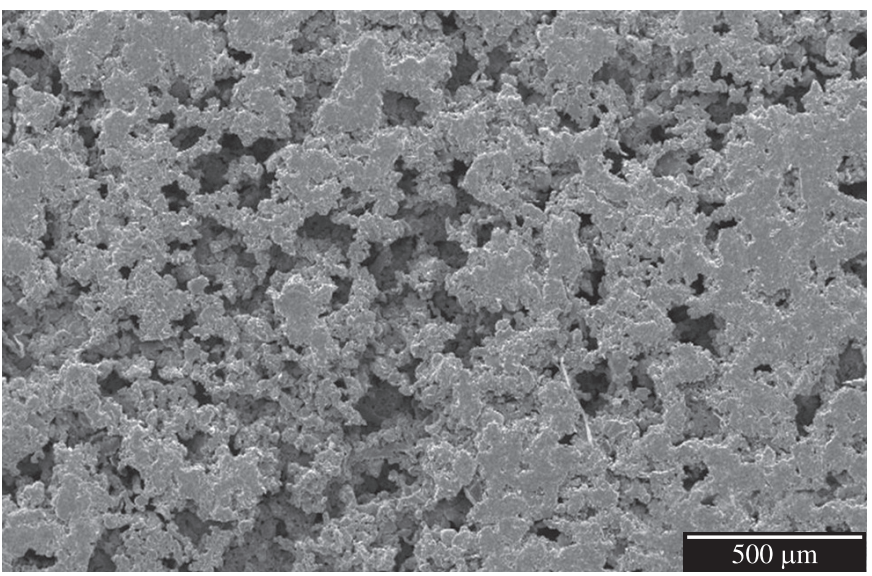

(a)

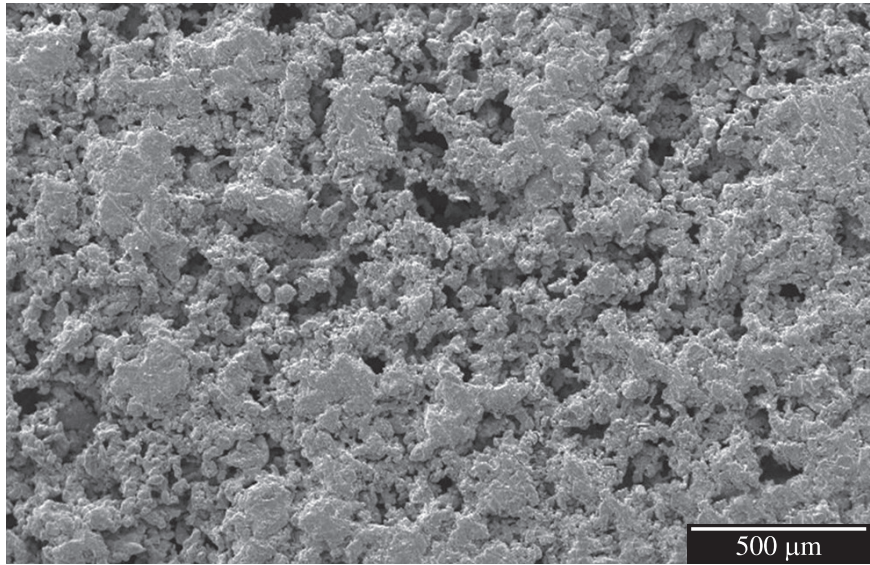

(c)

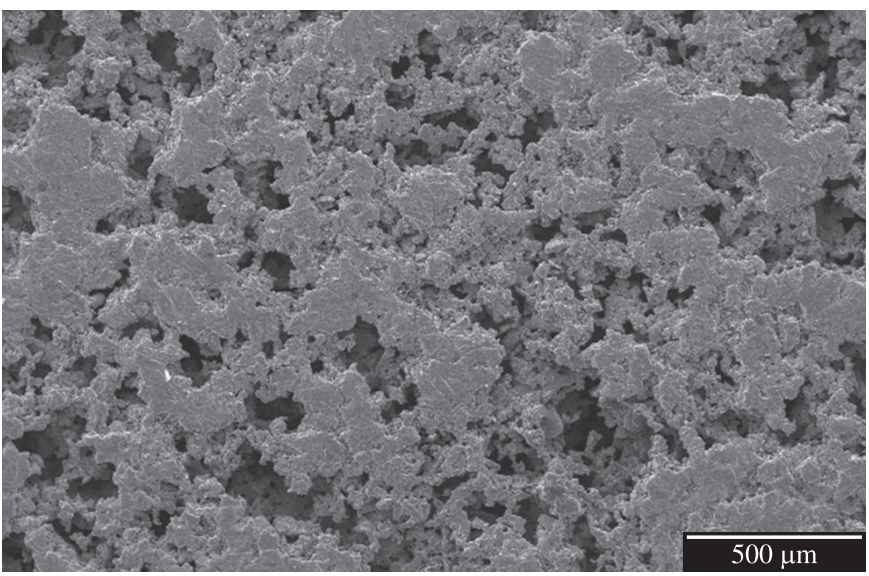

(b)

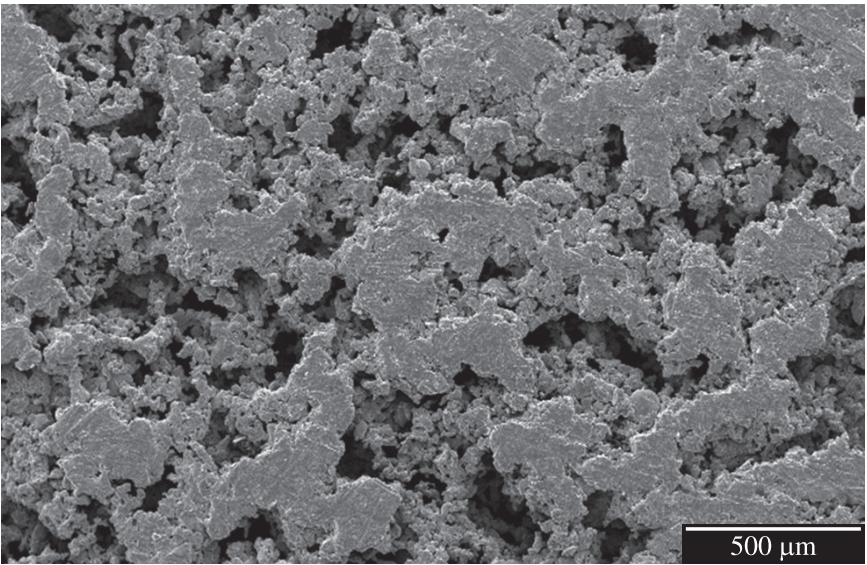

(d)

Figure 2. SEM micrographs of 316L stainless steel foams: a) $15 \mathrm{wt}$. (\%) ammonium carbonate; b) 15 wt. (\%) ammonium bicarbonate; c) $30 \mathrm{wt}$ ( $\%$ ) ammonium carbonate; and d) $30 \mathrm{wt}$. (\%) ammonium bicarbonate.

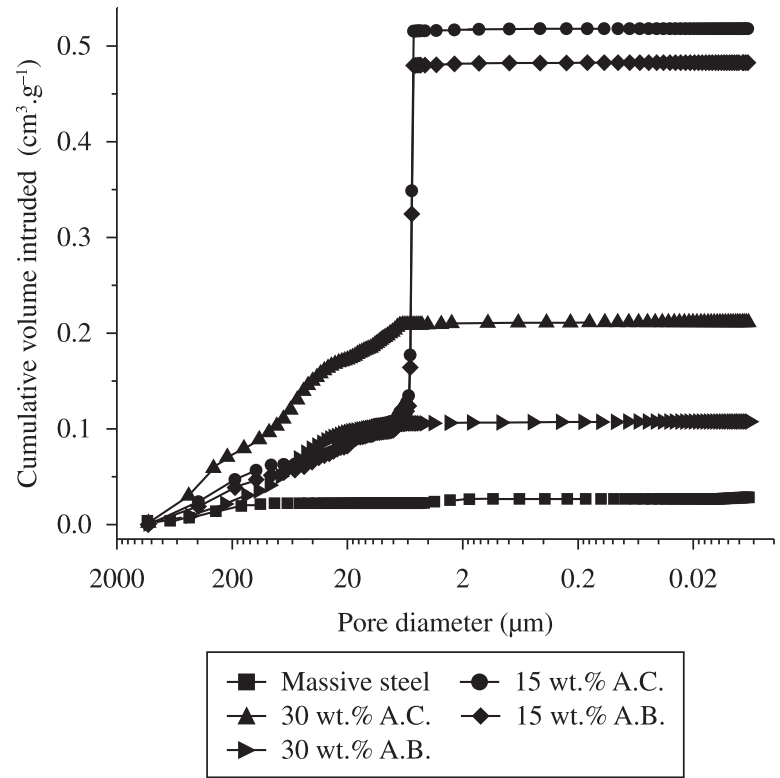

Figure 3. Pore size distribution in 316L stainless steel foams obtained with 15 and 30 wt. (\%) ammonium carbonate and bicarbonate.

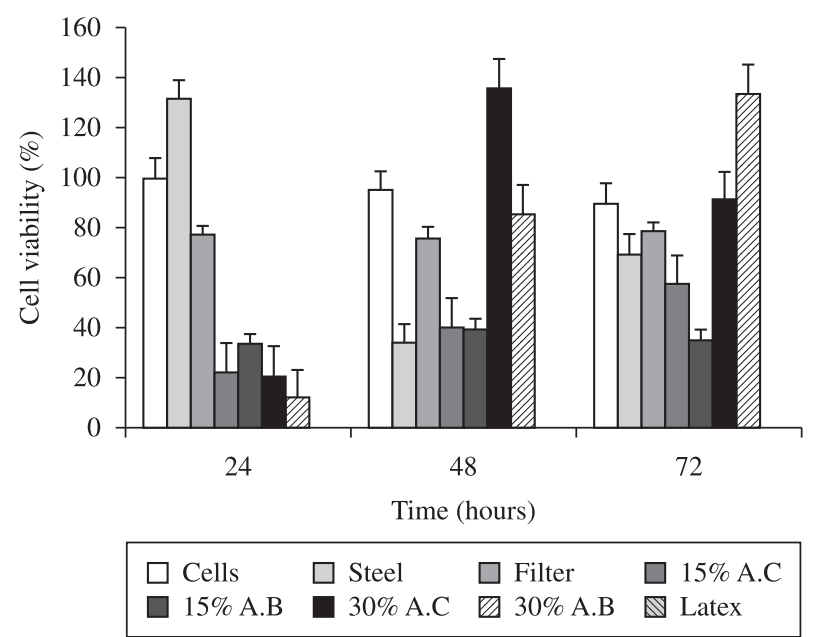

Figure 4. Cytotoxicity test - cultivated cells on samples of pure steel and steel with foaming agents: ammonium carbonate and ammonium bicarbonate. The symbols A.B. and A.C. correspond to ammonium bicarbonate and ammonium carbonate, respectively. 
recovered for all porous samples, but the recuperation was much more pronounced for the samples produced with $30 \mathrm{wt}$. (\%) foaming agents. For the period of 72 hours, it was observed a normalization of the cell viability to the levels found in the controls in the samples produced with ammonium carbonate (15 and 30 wt. (\%)). Considering the samples produced with ammonium bicarbonate, that with $15 \mathrm{wt} .(\%)$ showed low cell viability after 72 hours, the lowest among all the porous samples, while the $30 \mathrm{wt}$. (\%) sample showed a significant increase in cell viability when compared with the control groups.

Figure 5 shows micrographs obtained by SEM of the $316 \mathrm{~L}$ stainless steel after incubation with the cells for 48 and 72 hours.
After 48 hours the cells were homogeneously distributed over the sample already showing filament branching. After 72 hours, the whole sample is completely covered by cells. Arrows on Figure 5a show examples of cells and of the beginning of filaments formation.

Figures 6 and 7 present micrographs by SEM of the proliferation of cells on porous samples produced, respectively, with 15 and $30 \mathrm{wt}$. (\%) foaming agents. Variations observed in the cells interaction with samples were related to the porosity and foaming agent. The porous samples produced with ammonium bicarbonate, independent of the porosity, did not favor the cell proliferation and adhesion. Figures $6 \mathrm{a}$ and $7 \mathrm{a}$ obtained after 48 hours of incubation

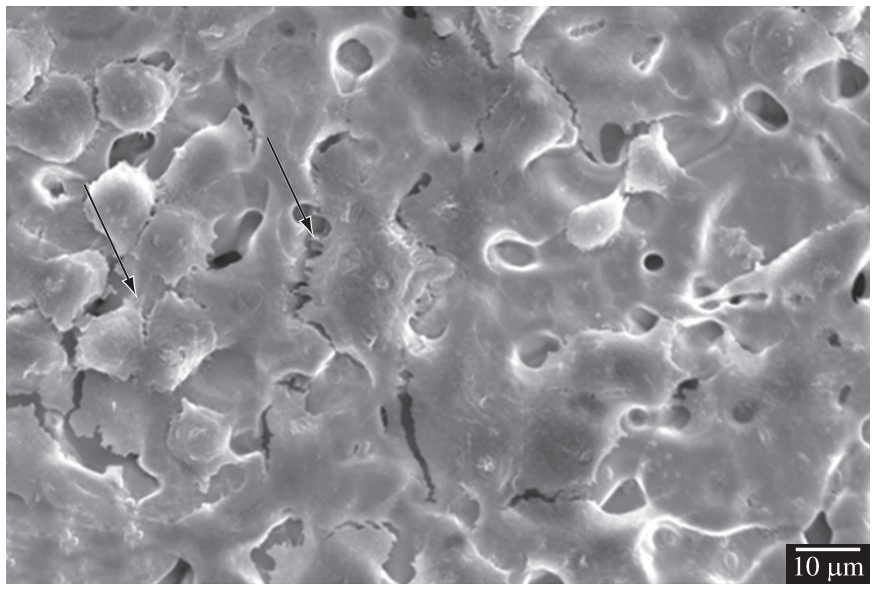

(a)

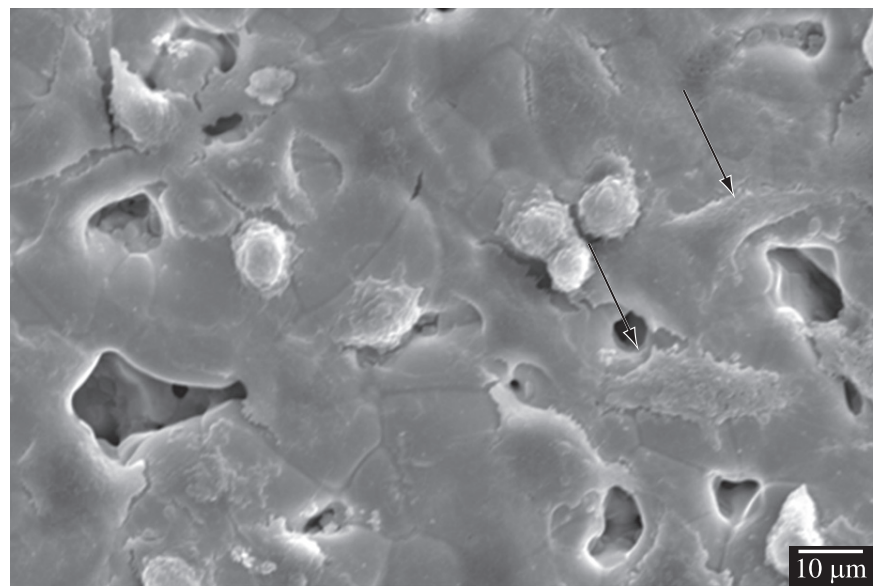

(b)

Figure 5. Proliferation of L292 cells by SEM on stainless steel 316L: a) after incubation with cells for 48 hours; b) after incubation with cells for 72 hours.

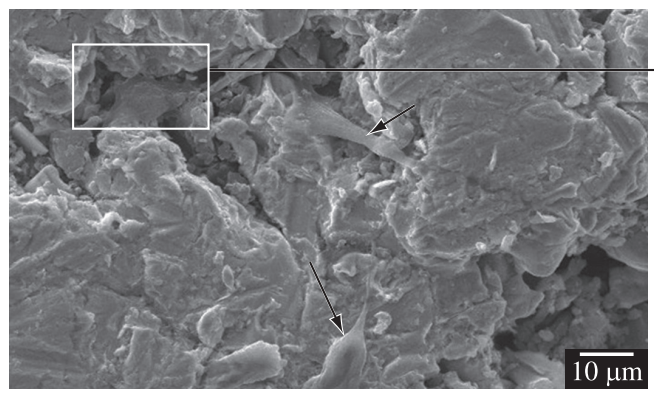

(a)

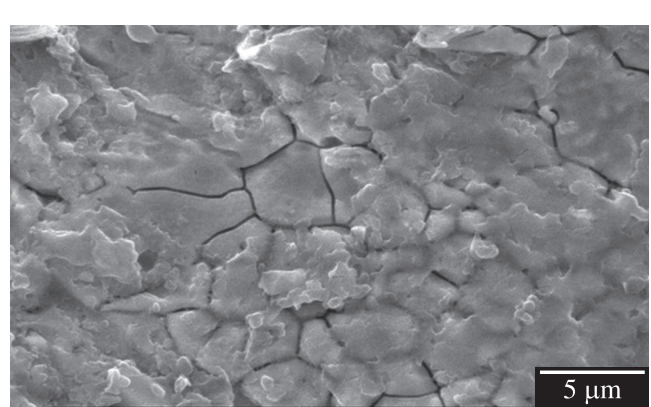

(c)

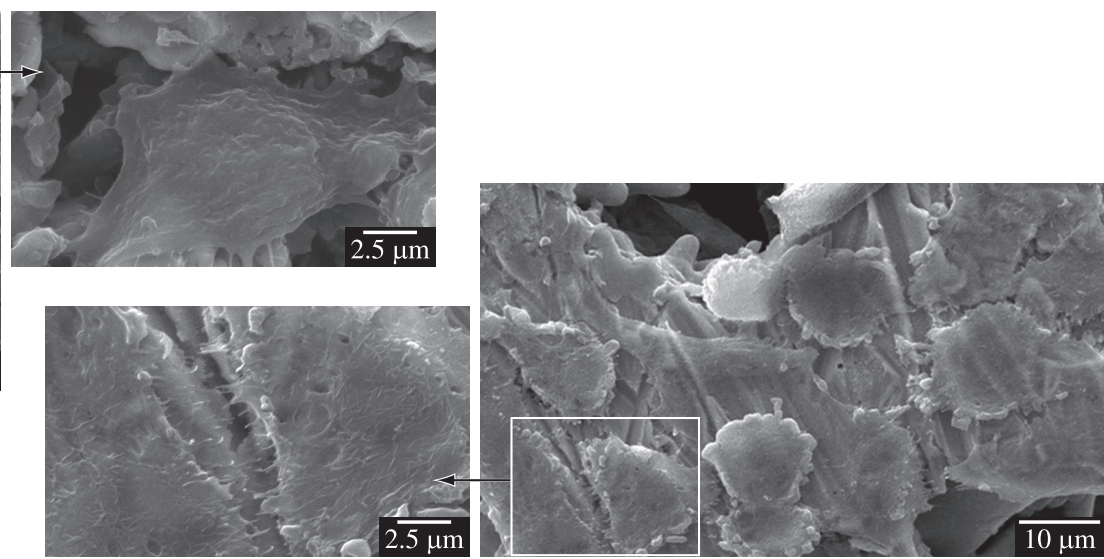

(b)

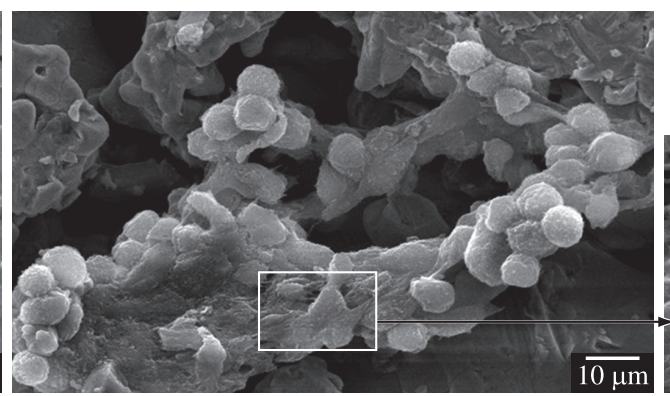

(d)

Figure 6. Proliferation of L292 cells by SEM: a) on samples with 15 wt. (\%) Ammonium Bicarbonate after incubation for 48 hours; b) on samples with 15 wt. (\%) Ammonium Carbonate after incubation for 48 hours; c) on samples with 15 wt. (\%) Ammonium Bicarbonate after incubation for 72 hours and d) on samples with 15 wt. (\%) Ammonium Carbonate after incubation for 72 hours. 
show that only some cells were adhered on the samples. These cells have a flat morphology and present some filaments. Figure $6 \mathrm{c}$ shows the spreading of some cells after 72 hours on sample produced with 15 wt. (\%) ammonium bicarbonate, while Figure 7c show only isolated cells (arrows) on samples produced with 30 wt. (\%) ammonium bicarbonate. This late condition proved to be the worst for cellular development, which may be related to the pore size distribution, a monomodal distribution with a mean diameter of $70 \mu \mathrm{m}$.

The use of ammonium carbonate in the production of porous samples seems to promote the adhesion and proliferation of cells. Figure $6 \mathrm{~b}$ show SEM micrographs where cells showing a flat morphology and cytoplasmic webbing (micrograph of higher magnification attached to Figure $6 b$ ) are well distributed on the sample produced with 15 wt. (\%) ammonium carbonate. After 72 hours, a large amount of cells is observed, Figure 6d, with a spherical morphology and cytoplasmic prolongations connecting the cells. The adhesion and proliferation of cells had also occurred on samples produced with $30 \mathrm{wt}$. (\%) of ammonium carbonate. In this case, already after 48 hours the cells show a spherical morphology, Figure $7 b$. The presence of cells with spherical morphology on these samples shows that there was cellular division and the sequence of cellular development agrees with the model proposed by Rajaraman et al. ${ }^{20}$. The model proposes that the major events in the process of adhesion and spreading seem to be attachment of the cell to the substratum, radial growth of filopodia, cytoplasmic webbing and the resultant flattening of the cell. During mitosis a reversal of these events occurs by cytoplasmic de-webbing, the cell becomes spherical while anchored to the substratum by long filopodia and after mitosis, the two daughter cells become flat again by cytoplasmic webbing. It should be emphasized that these different stages are not discretely separable but are different phases of a contiguous process. The duration of these phases and the degree of overlapping of these events may vary between different cell lines and different substrates ${ }^{20}$.

In this work, the cell growth was more apparent in samples with 15 and 30 wt. (\%) ammonium carbonate, which presented two wide pore size distributions at 20 and $300 \mu \mathrm{m}$, and 50 and $450 \mu \mathrm{m}$, respectively. This result is in accordance with optimum pore size required for implant fixation, between 100 and $400 \mu \mathrm{m}$, described in literature ${ }^{1,16-19}$. These samples presented cells covering the material and cellular division. It is important to emphasize that the cells were initially in suspension and after 24 hours were already interacting with the material. The cells that were not on the surface of the sample had normal proliferation, which was verified in the graphs of cytotoxicity. The interaction of the cells with the material surface is considered very important to the effectiveness of medical implants and can determine the degree of rejection. The chemistry of materials surface can determine the cellular response to the material and affect the cellular adhesion, proliferation, migration, and function ${ }^{21-24}$.

The results of cytotoxicity and SEM showed that the foaming agent and pore size influenced the interactions between cells and substrate. The fibroblasts in contact with the samples, had adhesion, proliferation, migration, and cellular viability for the culture intervals studied, but less than in the controls. The material did not release any toxic substances to disturb cellular growth.

The potentiodynamic polarization curves for three different samples of steels (316L massive steel (A), 316L steel foam with 15 wt. (\%) ammonium bicarbonate (B) and 316L steel foam with

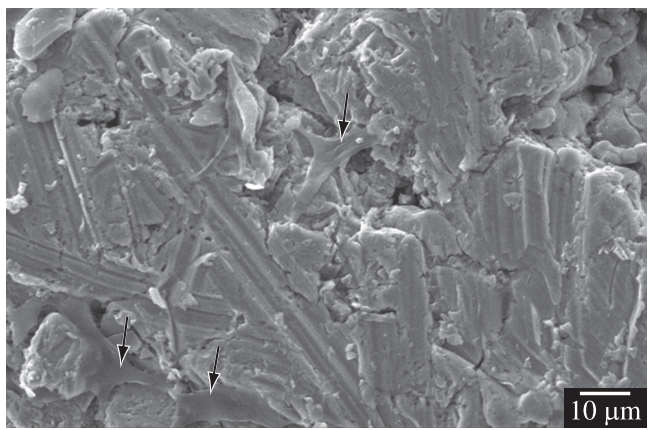

(a)

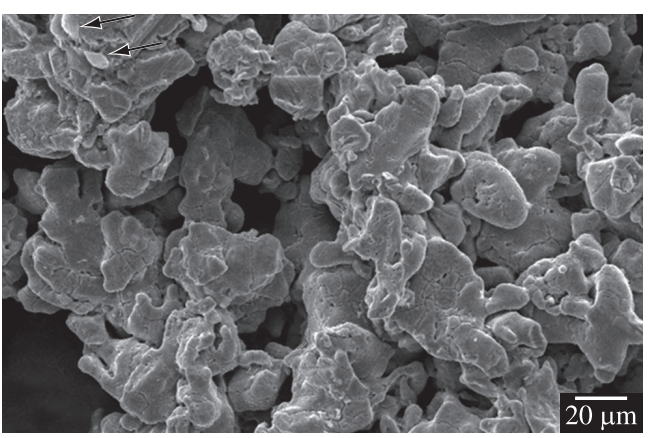

(c)

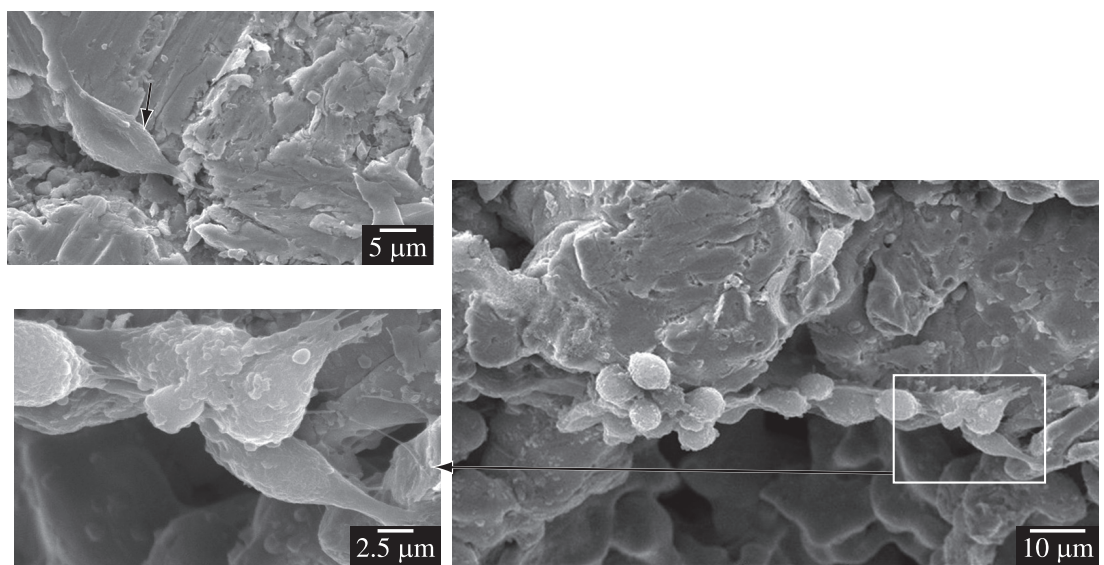

(b)
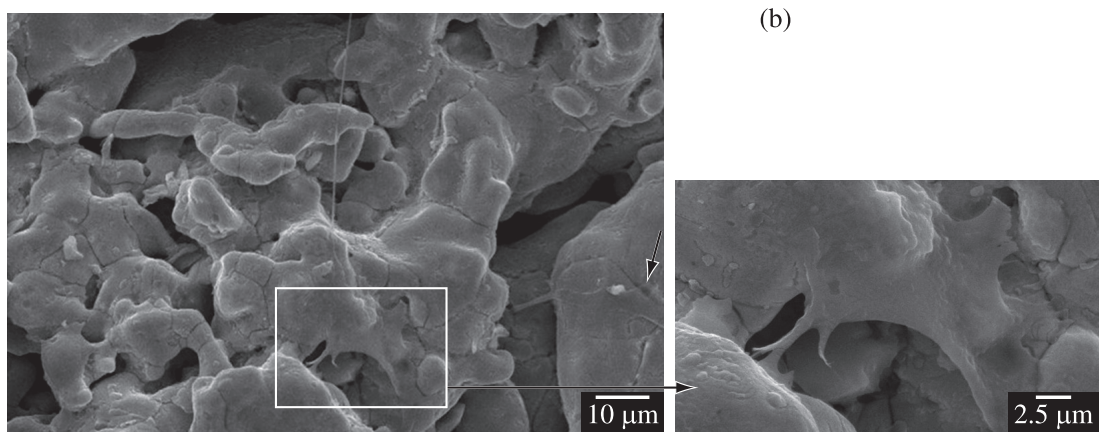

(d)

Figure 7. Proliferation of L292 cells by SEM: a) on samples with 30 wt. (\%) Ammonium Bicarbonate after incubation for 48 hours; b) on samples with $30 \mathrm{wt}$. (\%) Ammonium Carbonate after incubation for 48 hours; c) on samples with $30 \mathrm{wt}$. (\%) Ammonium Bicarbonate after incubation for 72 hours and d) on samples with 30 wt. (\%) Ammonium Carbonate after incubation for 72 hours. 
15 wt. (\%) ammonium carbonate (C)) in contact with 0.1 mol. $\mathrm{L}^{-1}$ $\mathrm{NaCl}$ aqueous solution, pH 5.9 are shown in Figure 8. The values of potential observed for the sets of measurements are in agreement with the literature ${ }^{25}$. The values vary between 0.18 and $0.27 \mathrm{~V}$. Table 4 shows the electrochemical parameters from the potentiodynamic polarization curves. Comparing the electrochemical parameters, the anodic current density $\left(\mathrm{j}_{\text {corr }}\right)$ is lower when the surface is the massive steel (A). The steel foams produced with $15 \mathrm{wt}$. (\%) ammonium bicarbonate (B) and 15 wt. (\%) ammonium carbonate (C) presented similar values of anodic current densities, but these values are four times higher than the massive steel value (A). The massive steel presented better corrosion performance in a chloride-containing medium.

Table 4. Electrochemical parameters obtained from polarization curves.

\begin{tabular}{lcc}
\hline \multicolumn{1}{c}{ 316L Steel Surface } & ${ }^{\mathrm{a}} \mathrm{E}_{\text {corr }}$ & ${ }^{\mathrm{b}} \mathrm{j}_{\text {corr }}$ \\
\hline (A) massive & $-0.18 \mathrm{~V}$ & $0.047 \mathrm{~mA}$ \\
(B) 15 wt. (\%) ammonium bicarbonate & $-0.15 \mathrm{~V}$ & $0.196 \mathrm{~mA}$ \\
(C) 15 wt. (\%) ammonium carbonate & $-0.27 \mathrm{~V}$ & $0.195 \mathrm{~mA}$ \\
\hline
\end{tabular}

${ }^{a}$ corrosion potential, ${ }^{b}$ corrosion current density.

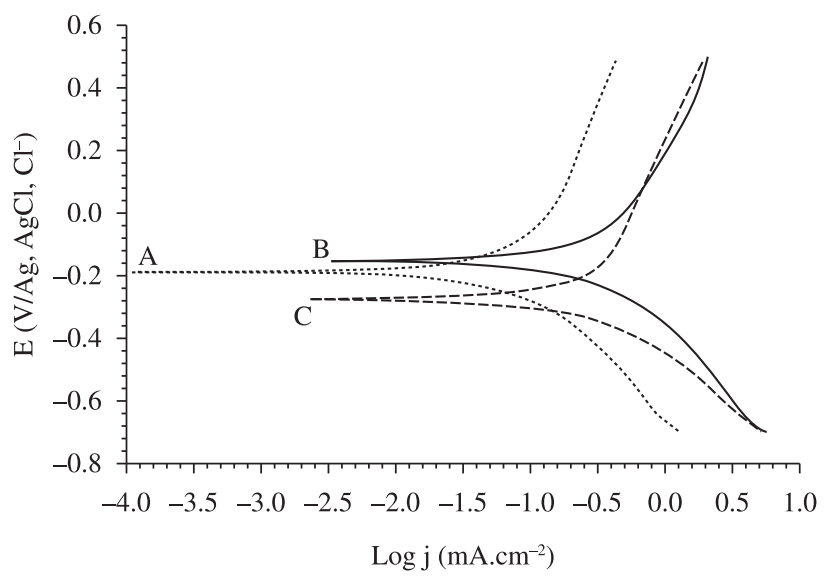

Figure 8. Potentiodynamic polarization curves of $316 \mathrm{~L}$ steels surface in 0.1 mol. $\mathrm{L}^{-1} \mathrm{NaCl}$ aqueous solution, $\mathrm{pH} 5.9$ at $25^{\circ} \mathrm{C}$ : A) massive; B) steel foam with 15 wt. (\%) ammonium bicarbonate; and C) steel foam with 15 wt. (\%) ammonium carbonate.

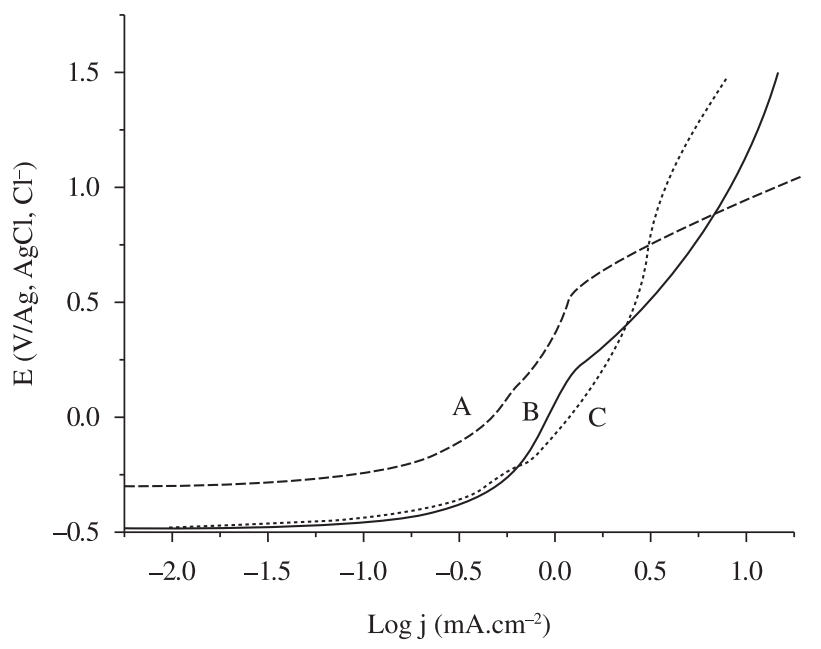

Figure 9. Anodic polarization curves for steel samples in 0.1 mol. $\mathrm{L}^{-1} \mathrm{NaCl}$ aqueous solution, pH 5.9 at $25{ }^{\circ} \mathrm{C}$. A) massive steel; B) steel foam with 15 wt. (\%) ammonium bicarbonate; and C) steel foam with 15 wt. (\%) ammonium carbonate.
Figure 9 shows the results of an anodic polarization test for the 316L massive steel (A), 316L steel foam with $15 \mathrm{wt}$. (\%) ammonium bicarbonate (B) and 316L steel foam with $15 \mathrm{wt}$ (\%) ammonium carbonate $(\mathrm{C})$. The samples was maintained for 24 hours at an open circuit potential, and then polarized anodically at a scanning rate of $10 \mathrm{mV} / \mathrm{s}$. An Ag/ $\mathrm{AgCl}, \mathrm{Cl}^{-}$was used as a reference electrode, platinum rod as a counter electrode and $0.79 \mathrm{~cm}^{2}$ disc shaped exposed area as working electrode. The three types of steels showed a current density of between -0.50 and $0.25 \mathrm{~mA} . \mathrm{cm}^{-2}$. Comparing the results of Figure 8 and 9 one can observe differences which can be attributed to a passivation effect of the steel surface ${ }^{26}$. The change in the corrosion potential value can be justified by the attack of the species, which cross the pores of the steel foams, forms a layer of passivated material stopping the progress of the corrosion.

\section{Conclusions}

Steel foams with relative densities of 0.3 and 0.5 were successfully obtained by powder metallurgy using the two foaming agents: ammonium carbonate and ammonium bicarbonate.

Very heterogeneous pore structures, composed by irregular and isolated pores, were obtained. Large and/or coalesced pores were observed on the surface; while smaller and isolated pores could be seen in the middle of the samples. Steel foams produced with $30 \mathrm{wt}$. (\%) foaming agents showed larger pores, more homogeneous in size and distribution than that with $15 \mathrm{wt}$. (\%) samples.

The steel foams were not toxic to fibroblasts culture. The samples that presented better cell viability were produced with $30 \mathrm{wt}$. (\%) foaming agents. Adhesion and cell growth was higher in the $30 \mathrm{wt}$. (\%) ammonium carbonate. Cell development was observed after 48 hours of incubation and after 72 hours, there was adhesion and spreading on the material. This sample presented the best pore size distribution to improve cell growth, a trimodal distribution, with mean diameters of 10,50 , and $450 \mu \mathrm{m}$.

Massive steel had better corrosion performance in a chloridecontaining medium than the steel foams, because porosity contributed to increased display area in the corrosive medium.

Although new experiments, such as mechanical and in vivo tests, are necessary, the results show that the steels foams produced in this work can be viable in orthopedic implants.

\section{Acknowledgements}

The authors acknowledge the METALPÓ by 316L stainless steel powder and the LCP/INPE by helium picnometry and mercury porosimetry analysis.

\section{References}

1. Ryan G, Pandit A and Apatsidis DP. Fabrication methods of porous metals for use in orthopaedic applications. Biomaterials. 2006; 27:2651-2670. PMid:16423390. doi:10.1016/j.biomaterials.2005.12.002

2. Wen EC, Yamada Y and Hodgson PD. Fabrication of novel TiZr alloy foams for biomedical applications. Materials Science and Engineering A. 2006; 26:1439-1444. doi:10.1016/j.msec.2005.08.006

3. Alvarez K, Sato K, Hyun SK and Nakajima H. Fabrication and properties of Lotus-type porous nickel-free stainless steel for biomedical applications. Materials Science and Engineering C. 2008; 28:44-50. doi:10.1016/j.msec.2007.01.010

4. Wen EC, Mabuchi M, Yamada Y, Shimojima K, Chino Y and Asahina $\mathrm{T}$. Processing of biocompatible porous Ti and Mg. Scripta Materialia. 2001; 45:1147-1153. doi:10.1016/S1359-6462(01)01132-0

5. Blackwood JD. Biomaterials: Past Successes and future problems. Corrosion Reviews. 2003; 21:97-124. 
6. Alvarez K, Hyun S-K, Nakano T, Umakoshi Y and Nakajima H. In vivo osteocompatibility of lotus-type porous nickel-free stainless steel in rats. Materials Science and Engineering C. 2009; 29:1182-1190. doi:10.1016/j. msec.2008.09.037

7. Ducheyne P. In vitro corrosion study of porous metal fibre coatings for bone ingrowth. Biomaterials. 1983; 4:185-91. doi:10.1016/01429612(83)90008-X

8. Seah KHW, Thampuran R and Teoh SH. The influence of pore morphology on corrosion. Corrosion Science. 1998; 40:547-56. doi:10.1016/S0010938X(97)00152-2

9. Manonukul A, Muenya N, Léaux F and Amaranan S. Effects of replacing metal powder with powder space holder on metal foam produced by metal injection moulding. Journal of Materials Processing Technology. 2010; 210:529-535. doi:10.1016/j.jmatprotec.2009.10.016

10. Shiomi M, Imagama S, Osakada K and Matsumoto R. Fabrication of aluminium foams from powder by hot extrusion and foaming. Journal of Materials Processing Technology. 2010; 210:1203-1208. doi:10.1016/j. jmatprotec.2010.03.006

11. Gu YW, Yong MS, Tay BY and Lim CS. Synthesis and bioactivity of porous Ti alloy prepared by foaming with TiH2. Materials Science and Engineering C. 2009; 29:1515-1520. doi:10.1016/j.msec.2008.11.003

12. Park $C$ and Nutt SR. Effects of process parameters on steel foam synthesis. Materials Science and Engineering A. 2001; 297:62-68. doi:10.1016/ S0921-5093(00)01265-X

13. Park $C$ and Nutt SR. PM synthesis and properties of steel foams. Materials Science and Engineering A. 2000; 288:111-118. doi:10.1016/S09215093(00)00761-9

14. Nouri A, Hodgson PD and Wen CE. Effect of process control agent on the porous structure and mechanical properties of a biomedical Ti-Sn-Nb alloy produced by powder metallurgy. Acta Biomaterialia. 2010; 6:16301639. PMid:19815096. doi:10.1016/j.actbio.2009.10.005

15. Mosman T. Rapid colorimetric assay for cellular growth and survival: application to proliferation and cytotoxicity assays. Journal of Immunological Methods. 1983; 65(1-2):55-63. doi:10.1016/00221759(83)90303-4
16. Kanetake $\mathrm{N}$ and Kobashi M. Innovative processing of porous and cellular materials by chemical reaction. Scripta Materialia. 2005; 54:521-525. doi:10.1016/j.scriptamat.2005.10.063

17. Dias CR, Kisaki Y, Ungaretti Neto A, Bredemeier Neto F, Tarragô R and Schwartsmann RC. Estudo experimental da reação tecidual óssea ao titânio Ti6A14V recoberto com hidroxiapatita. Revista Brasileira de Ortopedia. 1993; 28(6):407-412.

18. Barbanti HS and Duek RAE. Polímeros bioreabsorvíveis na engenharia de tecidos. Polímeros. 2005; 15:13-21.

19. Kawachi YE, Bertran AC, Reis RR and Alves LO. Biocerâmicas: Tendências e perspectivas de uma área interdisciplinary. Química Nova. 2000; 23:518-522. doi:10.1590/S0100-40422000000400015

20. Rajaraman R, Rounds DE, Yen SPS and Rembaum A. A scanning electron microscope study of cell adhesion and spreading in vitro. Experimental Cell Research. 1974, 88:327-339. doi:10.1016/0014-4827(74)90248-1

21. Gradzka-Dahlke M, Dabrowski RJ and Dabrowski B. Characteristic of the porous 316 stainless steel for the friction element of prosthetic joint. Wear. 2007; 263(7-12):1023-1029.

22. Boyan BD, Hummert TW, Dean DD and Schwartz Z. Role of material surfaces in regulating bone and cartilage cell response. Biomaterials. 1996; 17(2):137-146. doi:10.1016/0142-9612(96)85758-9

23. Dee KC, Andersen TT and Bizios R. Design and function of novel osteoblast- adhesive peptides for chemical modification of biomaterials. Journal of Biomedical Materials Research. 1998; 40(3):371-377. doi:10.1002/(SICI)1097-4636(19980605)40:3<371::AIDJBM5>3.0.CO;2-C

24. Lauffenburger DA and Horwitz AF. Cell migration: A physically integrated molecular process. Cell. 1996; 84(3):359-369. doi:10.1016/ S0092-8674(00)81280-5

25. Jones DA. Principle and Prevention of Corrosion. New York: Maxwell Macmillan International Editions; 1992.

26. Yoo YR, Jang SG, Oh KT, Kim JG and Kim YS. Influences of Passivating Elements on the Corrosion and Biocompatibility of Super Stainless Steels. Journal of Biomedical Materials Research Part B: Applied Biomater. 2008; 86B:310-320. PMid: 1816179. doi:10.1002/jbm.b.31018 